\title{
2-Mercaptobenzoxazole Pentacyanoferrate(II/III) Complexes: UV-Visible, Mössbauer, Electron Paramagnetic Resonance, Electrochemistry and Molecular Modeling
}

Juciane B. Luiz, Fabiano M. de Andrade ${ }^{a}$, Eduardo L. de Sá ${ }^{a}$, Geraldo R. Friedermann ${ }^{a}$, Antonio S. Mangrich $^{a}$, J. Elaine Barclay, David J. Evans ${ }^{b}$, Tai Hasegawa ${ }^{c}$ and Fábio S. Nunes ${ }^{*, a}$

${ }^{a}$ Departamento de Química, Universidade Federal do Paraná, Centro Politécnico, CP 19081, 81531-990 Curitiba - PR, Brazil

${ }^{b}$ Department of Biological Chemistry, John Innes Centre, Norwich Research Park, Norwich NR4 7UH, UK

${ }^{c}$ Henry Taube Institute, 897 Embarcadero Road, Palo Alto, CA 94303, USA

\begin{abstract}
Os complexos 2-mercaptobenzoxazol pentacianoferrato(II/III), $\left[\mathrm{Fe}^{\mathrm{II} / \mathrm{III}}(\mathrm{CN})_{5}(\mathrm{bzoxs})\right]^{3-/ 2-}$, foram preparados em solução (mistura $\mathrm{MeOH} / \mathrm{H}_{2} \mathrm{O} 75: 25 \%$ ) e caracterizados por técnicas espectroscópicas UV-Vis, Mössbauer, ressonância paramagnérica eletrônica (epr) e eletroquímica-voltametria cíclica. Os espectros de absorção no UV-Vis e de epr, juntamente com o comportamento eletroquímico sugeriram a coordenação do ligante polifuncional $N, S, O$-doador, bzoxs, através do átomo de enxofre ao íon de ferro(III). Os parâmetros de campo cristalino $\left(\mathrm{D}_{\mathrm{qL}}\right.$ e $\left.\mathrm{D}_{\mathrm{t}}\right)$ calculados para o complexo de ferro(II) e a reversibilidade do processo redox: $\mathrm{Fe}^{\mathrm{III}}$-bzoxs $+\mathrm{e}^{-} \rightarrow \mathrm{Fe}^{\mathrm{II}}$-bzoxs, também apontaram para a coordenação de bzoxs via átomo de enxofre. Os resultados foram complementados pelo estudo comparativo das propriedades de complexos pentacianoferrato contendo outros ligantes monodentados $N$-, $S$ - $e O$-doadores. Cálculos em nível $a b$ initio fornecem a composição dos orbitais de fronteira do ligante bzoxs e estão de acordo com o modo de ligação proposto a partir dos resultados experimentais.
\end{abstract}

2-Mercaptobenzoxazole pentacyanoferrate(II/III) complexes, $\left[\mathrm{Fe}^{\mathrm{II} / I I I}(\mathrm{CN})_{5}(\mathrm{bzoxs})\right]^{3-2-2}$, were prepared in $\mathrm{MeOH} / \mathrm{H}_{2} \mathrm{O}$ 75:25\% solutions and characterized by spectroscopic UV-Vis, Mössbauer, electron paramagnetic resonance (epr) and electrochemical-cyclic voltammetry- techniques. UV-Vis and epr spectra along with the electrochemical behavior suggested the coordination of the multifunctional $N, S, O$ - donor ligand, bzoxs, to iron(III) through the sulfur atom. The crystal field parameters, $\mathrm{D}_{\mathrm{qL}}$ and $\mathrm{D}_{\mathrm{t}}$, calculated for the iron(II) complex, in addition to the reversible redox process Fe $\mathrm{F}^{\mathrm{III}}$-bzoxs $+\mathrm{e}^{-} \rightarrow \mathrm{Fe}^{\mathrm{II}}$-bzoxs also pointed to coordination via the sulfur atom. The results were compared with the chemical properties of pentacyanoferrate complexes containing other monodentate $N$-, $S$ - and $O$ donor ligands. A $b$ initio calculations revealed the composition of the frontier orbitals of bzoxs and are in agreement with the mode of coordination proposed from the experimental data.

Keywords: 2-mercaptobenzoxazole, pentacyanoferrate, spectroscopy, crystal field parameters, ab initio calculations, electrochemistry

\section{Introduction}

Substituted pentacyanoferrate(II/III) complexes, $\left[\mathrm{Fe}(\mathrm{CN})_{5} \mathrm{~L}\right]^{\mathrm{n}-}$, have been studied extensively over the past decades. ${ }^{1}$ These low-spin complexes are useful synthetic models for biological systems and have been used to probe specific binding sites in amino acids, ${ }^{2}$ multi-functional ligands $^{3}$ and redox metalloproteins. ${ }^{4}$

The coordination of 2-mercaptobenzoxazole (bzoxs)

\footnotetext{
* e-mail: fsnunes@quimica.ufpr.br
}

to transition-metal ions is of special interest because of the efficiency of this ligand as a corrosion inhibitor, an important regulator of plant growth, showing a marked bacteriostatic and fungicidal activity. ${ }^{5}$ Proteins containing thiol groups that undergo nitrosation may modulate cellular functions and thiolate-complexes such as the $\left[\mathrm{Fe}(\mathrm{CN})_{5} \mathrm{~N}(\mathrm{O}) \mathrm{SR}\right]^{3-}(\mathrm{SR}=$ mercaptosuccinate $)$ have been investigated for possible in situ generation of biologically important NO species. ${ }^{6}$ Bzoxs is structurally related to biological important bases, having more than one donor atom to bind transition-metal ions (Scheme 1). ${ }^{7}$ Both in the solid state and in polar solvents it exists as the thione 


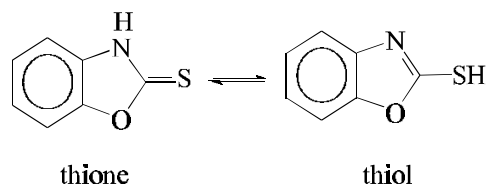

Scheme 1.

tautomer with the protonated N-atom., ${ }^{7,8}$ Most of the electron density of the oxygen is in resonance with the aromatic ring making it a poor donor atom. Although $\mathrm{S} \leftrightarrow \mathrm{N}$ linkage isomerism in bzoxs complexes is possible, no evidence has ever been published. Previous reports focused on the iron(II) form of the pentacyanoferrate ion, $\left[\mathrm{Fe}^{\mathrm{II}}(\mathrm{CN})_{5} \mathrm{~L}\right]^{\mathrm{n}-}$, with little effort devoted to the characterization of the oxidised form. ${ }^{9,10}$ We have now observed that bzoxs reacts with $\left[\mathrm{Fe}^{\mathrm{II}}(\mathrm{CN})_{5}\left(\mathrm{H}_{2} \mathrm{O}\right)\right]^{3-}$ and $\left[\mathrm{Fe}^{\mathrm{III}}(\mathrm{CN})_{5}\left(\mathrm{H}_{2} \mathrm{O}\right)\right]^{2-}$ giving solutions which are yellow and green, respectively. The complexes were characterized in detail by UV-Vis, epr, Mössbauer, cyclic voltammetry and theoretical calculations.

\section{Experimental}

\section{Materials}

$\mathrm{Na}_{3}\left[\mathrm{Fe}(\mathrm{CN})_{5}\left(\mathrm{NH}_{3}\right)\right] \cdot 3 \mathrm{H}_{2} \mathrm{O}(20 \mathrm{~g})$ was prepared from sodium nitroprusside by a standard procedure. ${ }^{11}$ It was recrystallized three times by saturating an aqueous solution containing $3 \mathrm{~mol} \mathrm{~L}^{-1} \mathrm{NH}_{3}$, at room temperature, and cooling overnight at $-15{ }^{\circ} \mathrm{C}$. The pure solid was collected on a filter, washed many times with $90 \%$ ethanol and dried under vacuum. The yellow product was stored in the dark at $-15{ }^{\circ} \mathrm{C}$. Anal. Calcd. for $\mathrm{Na}_{3}\left[\mathrm{Fe}(\mathrm{CN})_{5}\right.$ $\left.\left(\mathrm{NH}_{3}\right)\right] \cdot 3 \mathrm{H}_{2} \mathrm{O}: \mathrm{C}, 18.4 ; \mathrm{H}, 2.8 ; \mathrm{N}, 25.8 \%$. Found C, 18.0; H, $2.1 ; \mathrm{N}, 24.6 \%$.

The high purity of bzoxs (Aldrich) was confirmed by elemental analysis. Calcd. for $\mathrm{C}_{7} \mathrm{H}_{5} \mathrm{NOS}$ : C, 55.6; $\mathrm{H}, 3.3$; $\mathrm{N}, 9.3 \%$. Found C, 56.1; H, 3.3; N, 8.9\%. 2-merpatopyridine $N$-oxide (shpyNO) and benzoxazole (bzox) both Aldrich grade reagents were used as supplied.

Solutions of the aquopentacyanoferrate(II) complex were always freshly prepared, using Schlenk techniques, by dissolving $\mathrm{Na}_{3}\left[\mathrm{Fe}(\mathrm{CN})_{5}\left(\mathrm{NH}_{3}\right)\right] \cdot 3 \mathrm{H}_{2} \mathrm{O}$ in nitrogensaturated water. The mixture with a methanolic solution of bzoxs yielded final $\mathrm{MeOH} / \mathrm{H}_{2} \mathrm{O}(75: 25 \%)$ solutions with total iron concentration usually smaller than $10^{-4} \mathrm{~mol} \mathrm{~L}^{-1}$, except for the cyclic voltammetry measurements (see below) and a ligand to iron ratio of $c a$. 20-40 times.

Solutions of the aquopentacyanoferrate(III) complex were freshly prepared by oxidizing $\left[\mathrm{Fe}^{\mathrm{II}}(\mathrm{CN})_{5}\left(\mathrm{H}_{2} \mathrm{O}\right)\right]^{3-}$ (obtained from the aquation of $\left[\mathrm{Fe}^{\mathrm{II}}(\mathrm{CN})_{5}\left(\mathrm{NH}_{3}\right)\right]^{2-}$ ) with
$\mathrm{PbO}_{2}$ in nitrogen-saturated water. After removal of the excess of $\mathrm{PbO}_{2}$, it was mixed with a methanolic solution of bzoxs affording a clear deep-green solution.

\section{Measurements}

Electronic spectra in the UV-Vis range (190-820 nm) were obtained on a Hewlett-Packard Model 8452A diodearray or on a Shimadzu 2401-PC spectrophotometer in $\mathrm{MeOH} / \mathrm{H}_{2} \mathrm{O}(75: 25 \%)$ solutions.

Infrared spectra were obtained with a Bomen Hartmann $\&$ Braun MB series spectrophotometer in the region 4000$400 \mathrm{~cm}^{-1}$ as nujol mulls spread on $\mathrm{KBr}$ windows.

Determination of $\mathrm{pK}_{\mathrm{a}}$ values of 2-mercaptobenzoxazole were done by spectrophotometry with an acid-base titration of an aqueous solution of the ligand $\left(1 \times 10^{-5} \mathrm{~mol} \mathrm{~L}^{-1}\right)$ at $0.10 \mathrm{~mol} \mathrm{~L}^{-1} \mathrm{KCl}$. The experimental results for a single titration was expressed by the classical HendersonHasselbach equation: $\mathrm{pH}=\mathrm{pK}_{\mathrm{a}}-\log \left(\left[\mathrm{HL}^{+}\right] /[\mathrm{L}]\right)$, where $\left[\mathrm{HL}^{+}\right]$and $[\mathrm{L}]$ are the equilibrium concentrations of the protonated and deprotonated species, respectively. A plot of $\mathrm{pH} v s \log \left(\left[\mathrm{HL}^{+}\right] /[\mathrm{L}]\right)$ gives a straight line with slope close to unity. The $\mathrm{pH}$ values of the solutions were measured using a VWR Scientific $\mathrm{pH}$ meter Model 34100632 with a combined glass electrode.

$\mathrm{X}$-band electron paramagnetic resonance (epr) spectra were recorded on a Bruker ESP300-E instrument from frozen $\mathrm{MeOH} / \mathrm{H}_{2} \mathrm{O}(75: 25 \%)$ solutions $\left(1 \times 10^{-2} \mathrm{~mol} \mathrm{~L}^{-1}\right)$ at $77 \mathrm{~K}$.

Mössbauer data were recorded from frozen $\mathrm{MeOH} / \mathrm{H}_{2} \mathrm{O}$ (75:25\%) solutions at $77 \mathrm{~K}$ using an ES-Technology MS105 spectrometer with a $25 \mathrm{mCi}{ }^{57} \mathrm{Co}$ source in a rhodium matrix. Spectra were referenced against iron foil at $298 \mathrm{~K}$.

Cyclic voltammetry was carried out with a Princeton Applied Research Potentiostat model 273A. A platinum disc electrode was employed for the measurements at $\mathrm{I}=$ $0.5 \mathrm{~mol} \mathrm{~L}^{-1}$ kept constant with $\mathrm{TBABF}_{4}$ (tetrabutylammonium tetrafluoroborate). A $\mathrm{Ag} / \mathrm{AgNO}_{3}$ $\left(\left[\mathrm{Ag}^{+}\right]=0.01 \mathrm{~mol} \mathrm{~L}^{-1}\right.$ in an $\mathrm{MeCN}$ solution of $\mathrm{TBABF}_{4} 0.1$ mol L ${ }^{-1}$ ) along with a platinum wire were used as reference and auxiliary electrodes, respectively. Typical experiments were conducted with a $2.5 \times 10^{-3}$ mol L $\mathrm{L}^{-1}$ complex concentration in $\mathrm{MeOH} / \mathrm{H}_{2} \mathrm{O}(75: 25 \%)$ solutions at ambient temperature.

Molecular modeling were carried out for 2mercaptobenzoxazole in both the thione and thiol tautomers. Ab initio calculations using Hartree-Fock method and bases 6-311(d,f) were done using the Gaussian 94 program running under the UNIX FreeBSD 2.1.5 operational system in a personal computer. 


\section{Results and Discussion}

\section{Molecular modeling of bzoxs}

The calculated energy for the thione tautomer is $-2.09 \times 10^{6} \mathrm{~kJ} \mathrm{~mol}^{-1}, 28.3 \mathrm{~kJ} \mathrm{~mol}^{-1}$ more stable than the thiol form. This is in accordance with the large N-H stretching band at $3257 \mathrm{~cm}^{-1}$ and the absence of the band at $c a$. $2500 \mathrm{~cm}^{-1}$ typical of S-H stretching. The dominance of the thione in polar solvents such as methanol, as proved by ${ }^{15} \mathrm{~N}$ and ${ }^{13} \mathrm{C}$ experiments, ${ }^{8}$ agrees with the dipole moment of 6.47 D calculated for bzoxs in this work against $0.79 \mathrm{D}$ found for the thiol form.

The composition of HOMO showed a major contribution of sulfur and nitrogen $(\mathrm{S}, 0.60 ; \mathrm{N}, 0.50$; and $\mathrm{O}, 0.31$ for thione and $\mathrm{S}, 0.38 ; \mathrm{N}, 0.40$; and $\mathrm{O}, 0.0$ for thiol). The smaller difference gap between the energies of the HOMO and LUMO (0.39892 eV for thione versus $0.42349 \mathrm{eV}$ for thiol) shows that the thione is expected to behave as a softer base. The HOMO of thione has a greater contribution from the sulfur atom, suggesting the ability to stabilize soft ions while the LUMO orbital has the necessary $\pi$-symmetry to undergo backbonding interactions with iron(II).

The high negative Mülliken charges of the nitrogen atom in both tautomers $(\mathrm{N},-0.52 ; \mathrm{S},-0.25$ for thione and $\mathrm{N}$, -0.44; S, 0.066 for thiol) indicate a harder character when compared with those values for sulfur. This is consistent with the $\mathrm{pK}_{\mathrm{a}}$ values of 10.50 and 5.1 determined for the -NH and -SH groups, respectively, and should stabilize a coordination of nitrogen to the hard iron(III) Lewis acid.

\section{Electronic spectra}

The lowest energy band at $706 \mathrm{~nm}\left(\varepsilon=2 \times 10^{3} \mathrm{~mol}^{-1} \mathrm{~L}\right.$ $\left.\mathrm{cm}^{-1}\right)$ in the spectrum of $\left[\mathrm{Fe}^{\mathrm{III}}(\mathrm{CN})_{5}(\text { bzoxs })\right]^{2-}$ is assigned to a $\mathrm{p}_{\pi}(\mathrm{S}) \rightarrow \mathrm{d}_{\pi}\left(\mathrm{Fe}^{\mathrm{III}}\right)$ charge transfer transition, which is responsible for the deep-green color of the complex (Figure 1). Bands of this sort are not observed in the spectra of the $\mathrm{NH}_{3}{ }^{12}$ nor in the benzoxazole (bzox) complexes. However they are prominent in the spectra of pentacyanoferrate(III) complexes containing $S$-donor ligands such as, thiourea, $(595 \mathrm{~nm})^{13}$ 2-mercaptopyridine $(670 \mathrm{~nm}),{ }^{14} 3$-mercapto1,2,4-triazol $(693 \mathrm{~nm}),{ }^{15}$ mercaptosuccinate $(700 \mathrm{~nm})$, diethyldithiocarbamate $(785 \mathrm{~nm})^{6}$ and 2-mercaptopyridine$\mathrm{N}$-oxide (shpyNO) at $736 \mathrm{~nm}$, as seen in Figure 1. The bands in the 432-362 $\mathrm{nm}$ region for the iron(III) spectra of bzoxs, shpyNO and bzox complexes were assigned to a $\mathrm{p}_{\pi}\left(\mathrm{CN}^{-}\right) \rightarrow \mathrm{d}_{\pi}\left(\mathrm{Fe}^{\mathrm{III}}\right)$ charge-transfer as in the aquopentacyanoferrate(III) complex. ${ }^{16}$ Strong absorptions observed below $300 \mathrm{~nm}$ are due to intra-ligand transitions $\pi \rightarrow \pi^{*}$.

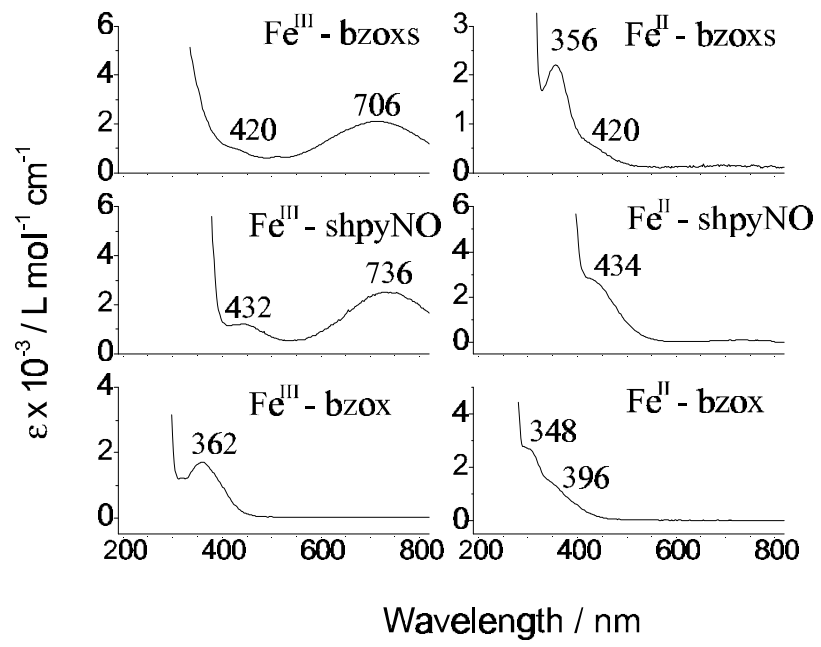

Figure 1. UV-visible spectra of $\left[\mathrm{Fe}^{\mathrm{III} / \mathrm{II}}(\mathrm{CN})_{5}(\mathrm{~L})\right]^{2-/ 3-}$ complexes, where $\mathrm{L}=2$-mercaptobenzoxazole (bzoxs), benzoxazole (bzox) and 2mercaptopyridine- $N$-oxide (shpyNO).

In $\left[\mathrm{Fe}^{\mathrm{II}}(\mathrm{CN})_{5} \mathrm{~L}\right]^{\mathrm{n}-}\left(\mathrm{d}^{6}\right)$ complexes of $\mathrm{C}_{4 \mathrm{v}}$ symmetry, two transitions are expected. The first $\left({ }^{1} \mathrm{~A}_{1} \rightarrow{ }^{1} \mathrm{~A}_{2}\right)$ is orbitally forbidden with very small extinction coefficient and only has been seen for the nitroprusside $\left(\mathrm{NO}^{+}\right)$complex at 330 $\mathrm{nm}\left(30.3 \mathrm{kK}, \varepsilon=40 \mathrm{~L} \mathrm{~mol}^{-} \mathrm{cm}^{-1}\right) .{ }^{17}$ The second transition has higher intensity than the first and has been assigned as ${ }^{1} \mathrm{~A}_{1} \rightarrow{ }^{1} \mathrm{E}_{(1)}{ }^{18}$ In contrast to the first transition (which is $\mathrm{d}_{\mathrm{xy}}$ $\left.\rightarrow \mathrm{d}_{\mathrm{x} 2-\mathrm{y} 2}\right)$, the ${ }^{1} \mathrm{~A}_{1} \rightarrow{ }^{1} \mathrm{E}_{(1)}\left(\mathrm{d}_{\mathrm{xz}}, \mathrm{d}_{\mathrm{yz}} \rightarrow \mathrm{d}_{\mathrm{z} 2}\right)$ transition is sensitive to the nature of the ligand $\mathrm{L}$ and has been reported for a large number of pentacyanoferrate(II) complexes between 264 to $444 \mathrm{~nm}$ (Table 1).

Solutions of $\left[\mathrm{Fe}^{\mathrm{II}}(\mathrm{CN})_{5}(\mathrm{~L})\right]^{3-}(\mathrm{L}=$ bzoxs and bzox $)$ are yellow with absorption bands at 356 and $348 \mathrm{~nm}$, respectively, and these are assigned as a $\mathrm{d}_{\pi}\left(\mathrm{Fe}^{\mathrm{II}}\right) \rightarrow \mathrm{p}_{\pi}(\mathrm{L})$ transition (Figure 1). A d-d ${ }^{1} \mathrm{~A}_{1} \rightarrow{ }^{1} \mathrm{E}_{(1)}$ transition was tentatively assigned around $420 \mathrm{~nm}$ (for bzoxs) and 396 $\mathrm{nm}$ (for bzox). The very close proximity of this band with the more intense MLCT band, makes a more accurate attribution difficult. A strong absorption is seen at $230 \mathrm{~nm}$ due to a $\mathrm{d}_{\pi}\left(\mathrm{Fe}^{\mathrm{II}}\right) \rightarrow \mathrm{p}_{\pi}\left(\mathrm{CN}^{-}\right)$charge transfer transition and overlaps with the $\pi \rightarrow \pi^{*}$ transitions of the ligands $\mathrm{L}$ (present in excess) at 210, 260 and $300 \mathrm{~nm}$. In $\left[\mathrm{Fe}^{\mathrm{II}}(\mathrm{CN})_{5}(\operatorname{shpyNO})\right]^{3-}$, all d-d bands are completely masked by the MLCT band at $434 \mathrm{~nm}$.

Determining the mode of coordination of bzoxs to $\mathrm{Fe}^{\mathrm{II}}$ is not so simple as for the $\mathrm{Fe}^{\mathrm{III}}$-bzoxs system, as revealed by the electronic spectra. To solve this problem, we determined $\mathrm{D}_{\mathrm{t}}$ and $\mathrm{D}_{\mathrm{qL}}$ based on a standard crystal field analysis. ${ }^{19}$ The energies of the d-d transitions are directly proportional to the ligand field strength and the values found suggest a sulfur coordination of bzoxs to iron(II) and are in accordance with other thioamide $S$-bonded ligands like thioacetamide (ta) and thiourea (tu) ${ }^{13}$ (Table 1). 
Table 1. Crystal field and Mössbauer parameters of pentacyanoferrate(II) complexes

\begin{tabular}{|c|c|c|c|c|c|c|c|c|}
\hline $\begin{array}{l}{\left[\mathrm{Fe}(\mathrm{CN})_{5} \mathrm{~L}\right]} \\
\mathrm{L}=\end{array}$ & donor group (donor atom) & $\begin{array}{l}{ }^{1} \mathrm{~A}_{1} \rightarrow{ }^{1} \mathrm{E}_{(1)} \\
\lambda_{\max }(\mathrm{nm})\end{array}$ & $\begin{array}{c}{ }^{1} \mathrm{~A}_{1} \rightarrow{ }^{1} \mathrm{E}_{(1)} \\
\text { Energy }(\mathrm{kK})\end{array}$ & $\begin{array}{c}\mathrm{D}_{\mathrm{t}}^{\mathrm{a}} \\
(\mathrm{kK}) \\
\end{array}$ & $\begin{array}{l}\mathrm{D}_{\mathrm{qL}}{ }^{\mathrm{a}} \\
(\mathrm{kK}) \\
\end{array}$ & $\begin{array}{c}\text { i.s } \\
\left(\mathrm{mm} \mathrm{s}^{-1}\right)\end{array}$ & $\begin{array}{c}\text { q.s, } \\
\left(\mathrm{mm} \mathrm{s}^{-1}\right)\end{array}$ & ref. \\
\hline $\mathrm{NO}^{+}$ & nitrosyl (N) & 264 & 37.9 & -0.393 & 4.60 & -0.257 & 1.71 & 19,21 \\
\hline $\mathrm{CO}$ & carbonyl (C) & 303 & 33.0 & -0.114 & 3.62 & -0.136 & 0.37 & 21 \\
\hline $\mathrm{CN}^{-}$ & nitrile $(\mathrm{C})$ & 322 & 31.1 & -0.003 & 3.23 & -0.05 & 0.00 & 19 \\
\hline dmso & sulfoxide $(\mathrm{S})$ & 352 & 28.4 & 0.148 & 2.70 & 0.0 & 1.10 & 19 \\
\hline $\mathrm{mpz}$ & imine $(\mathrm{N})$ & 380 & 26.3 & 0.268 & 2.28 & 0.06 & 1.10 & 19 \\
\hline imidazole & imine $(\mathrm{N})$ & 383 & 26.1 & 0.279 & 2.24 & $\mathrm{~b}$ & $\mathrm{~b}$ & 21 \\
\hline $\mathrm{pzCO}_{2}$ & imino-carboxylate $(\mathrm{N})$ & 386 & 25.9 & 0.291 & 2.20 & 0.08 & 0.96 & 19 \\
\hline bzox & secondary amine $(\mathrm{N})$ & 388 & 25.8 & 0.299 & 2.17 & 0.07 & 0.93 & $\mathrm{c}$ \\
\hline shpyNO & imino-thione (S) & masked & masked & $\mathrm{b}$ & $\mathrm{b}$ & 0.11 & 0.86 & c \\
\hline dms & sulfide $(\mathrm{S})$ & 395 & 25.3 & 0.325 & 2.08 & $\mathrm{~b}$ & $\mathrm{~b}$ & 21 \\
\hline dto & thioamide $(\mathrm{S})$ & 395 & 25.3 & 0.325 & 2.08 & $\mathrm{~b}$ & $\mathrm{~b}$ & 13 \\
\hline ta & thioamide (S) & 400 & 25.0 & 0.343 & 2.02 & $\mathrm{~b}$ & $\mathrm{~b}$ & 13 \\
\hline tu & thioamide (S) & 407 & 24.6 & 0.367 & 1.93 & $\mathrm{~b}$ & $\mathrm{~b}$ & 13 \\
\hline bzoxs & thioamide (S) & 420 & 23.8 & 0.411 & 1.78 & 0.09 & 0.78 & c \\
\hline
\end{tabular}

dmso = dimethylsulfoxide $\mathrm{mpz}=$ methylpyrazinium; $\mathrm{pzCO}_{2}=$ pyrazine carboxilate; bzox = benzoxazole; shpyNO = 2-mercaptopyridine $\mathrm{N}$-oxide; $\mathrm{dms}=$ dimethylsufide; dto $=$ dithiooxamide; ta $=$ thioacetamide; tu $=$ thiourea; bzoxs $=2$-mercaptobenzoxazole $;{ }^{\text {a }}$ Calculated according to ref. $19 ;{ }^{\mathrm{b}}$ Not determined; ${ }^{\mathrm{c}}$ This work.

Moving down in Table $1, \mathrm{D}_{\mathrm{qL}}$ values decrease as the $\sigma+\pi$ donor capacities increase. This tendency shows the smaller ability of the ligands (from top to the bottom) to stabilize the $\pi$ symmetry orbitals $\left(\mathrm{d}_{\mathrm{xz}}\right.$ and $\left.\mathrm{d}_{\mathrm{yz}}\right)$ relative to that of $\sigma$ symmetry $\left(\mathrm{d}_{z 2}\right)$, while $\mathrm{D}_{\mathrm{t}}>0$ indicates that bzoxs gives axial elongation. The fact that bzoxs is a weak ligand as indicated by the low $\mathrm{D}_{\mathrm{qL}}$ does not mean the corresponding $\left[\mathrm{Fe}^{\mathrm{III} / \mathrm{II}}(\mathrm{CN})_{5}(\text { bzoxs })\right]^{\mathrm{n}-}$ complexes lack stability. On the contrary, formation constants for both oxidation states have proven that bzoxs is indeed a fair $\pi$-acceptor and an even better $\sigma+\pi$ donor. ${ }^{9}$

\section{Cyclic voltammetry}

Cyclic voltammograms of $\left[\mathrm{Fe}(\mathrm{CN})_{5}(\mathrm{~L})\right]^{\mathrm{n}-}($ bzoxs and bzox) show typical quasi-reversible behavior, consistent with the existence of monomeric species in solution, with formal reduction potentials $\mathrm{E}^{\mathrm{f}}=0.190$ and $0.284 \mathrm{~V}$ versus SHE, respectively, and assigned to the $\mathrm{Fe}^{\mathrm{III}} \rightarrow \mathrm{Fe}^{\mathrm{II}}$ redox reaction (Figure 2). Considering the strong resemblance between the structures of the ligands bzoxs and bzox, the small but real difference between the reduction potentials suggests, again, different modes of coordination.

Compared to the high $\mathrm{E}_{\text {dmso }}^{\mathrm{f}}=0.85 \mathrm{~V} v s$ SHE found for $\left[\mathrm{Fe}^{\mathrm{III/I}}(\mathrm{CN})_{5}(\mathrm{dmso})\right]^{2-1 / 3-20}(\mathrm{dmso}=$ dimethylsulfoxide $)$ other thioamide $S$-bonded ligands (tu $=$ thiourea: $\mathrm{E}_{\mathrm{f}}=0.300 \mathrm{~V}$ and ta = thioacetamide: $0.405 \mathrm{~V} v s \mathrm{SHE}$ ) also showed low values of reduction potentials. ${ }^{13}$ Bzoxs behaves as a moderate $\pi$-acceptor as well as a strong $\sigma+\pi$ donor ligand, as it stabilizes both oxidation states of the pentacyanoferrate complexes $\left(\mathrm{K}_{\mathrm{f} \text { bzoxs }}^{\mathrm{II}}=7.8 \times 10^{5} v s \mathrm{~K}_{\mathrm{f}}^{\mathrm{III}}\right.$ bzoxs $\left.=8.6 \times 10^{8} \mathrm{~L} \mathrm{~mol}^{-1}\right) \cdot{ }^{9}$ The quasi-reversible electrochemical

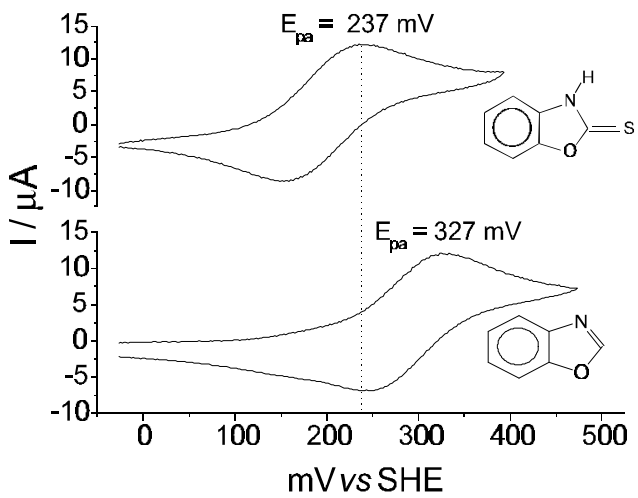

Figure 2. Cyclic voltammograms of $\left[\mathrm{Fe}^{\mathrm{III} / \mathrm{II}}(\mathrm{CN})_{5}(\mathrm{~L})\right]^{2-/ 3-}$ complexes $(\mathrm{L}=$ bzoxs and bzox $)$. Conditions: $\left[\mathrm{Fe}^{\mathrm{n}+}\right] \approx 2 \times 10^{-3} \mathrm{~mol} \mathrm{~L}^{-1}$; excess of $\mathrm{L}(20 \mathrm{x})$ in $\mathrm{MeOH} / \mathrm{H}_{2} \mathrm{O}(75 / 25 \% \mathrm{v} / \mathrm{v})$. $\mathrm{I}=0.5 \mathrm{~mol} \mathrm{~L}^{-1}\left(\mathrm{TBABF}_{4}\right)$.

behavior observed for the redox couple $\left[\mathrm{Fe}^{\mathrm{III} / \mathrm{II}}(\mathrm{CN})_{5}(\text { bzoxs })\right]^{3-2-2-}$ indicates no linkage isomerization coupled to the redox reaction and is consistent with the iron-sulfur bonding for both $\mathrm{Fe}^{\mathrm{III}}$ and $\mathrm{Fe}^{\mathrm{II}}$.

\section{Mössbauer data}

The Mössbauer spectra of the $\left[\mathrm{Fe}^{\mathrm{II}}(\mathrm{CN})_{5} \mathrm{~L}\right]^{3-}$ complexes are quadrupole split doublets as already seen in similiar studies. ${ }^{19,21}$ Table 1 presents isomer shifts (i.s.) and quadrupole splitting (q.s.) parameters calculated from the spectra, the data are in accordance with low-spin iron(II)..$^{19,21}$

The quadrupole splitting measures the asymmetry of the electric field at the nucleus, the extent of which is closely related to the $\sigma$ and $\pi$ metal-ligand bonding and therefore is sensitive to the nature of the ligand L. According to the data in Table 1, for those complexes which 
show axial elongation $\left(\mathrm{D}_{\mathrm{t}}>0\right)$, asymmetry decreases slightly in the order: $\mathrm{L}=\mathrm{dmso}=\mathrm{mpz}>\mathrm{pzCO}_{2}>$ bzox $>$ shpyNO > bzoxs. This is consistent with the ligand spectrochemical series with bzoxs being a better donor than an acceptor.

The isomer shift is also sensitive to the ligand (L) $\sigma$-donor and $\pi$-acceptor ability as it changes the electronic density at the iron nucleus. There is a clear tendency for i.s. values to increase from the top $\left(\mathrm{NO}^{+}\right)$to the bottom (bzoxs) of Table 1, although the data are slightly scattered. This can be easily rationalized when we consider that ligands with $\pi$-acceptor ability remove $\pi-3 d$ electron density from the iron through a back-bonding mechanism, reducing the shielding of the nucleus and causing an increase of the $s$ electron density at the metal. This causes a decrease in the isomer shift. The $\sigma$ ligand-metal bonding, which is more prominent for those ligands at the bottom of Table 1, also has the same effect on i.s. as it increases the $4 s$ population.

On the other hand, the increase in i.s. from $\mathrm{NO}^{+}$to bzoxs suggests that i.s. depends more on the relative abilities of the ligands to accept $\pi$-electrons rather than by their $\sigma$-donor properties.

\section{Electron paramagnetic spectra (epr)}

The epr spectrum of the benzoxazole complex, $\left[\mathrm{Fe}^{\mathrm{III}}(\mathrm{CN})_{5}(\text { bzox) }]^{2-}\right.$, at $77 \mathrm{~K}$ (Figure 3) shows broad lines with strong overlapping. A similar behavior was observed for $\mathrm{NH}_{3}$. When $\mathrm{L}=\mathrm{MeOH} / \mathrm{H}_{2} \mathrm{O}$, a typical spectrum of iron in rhombic symmetry is obtained, with $\mathrm{g}_{1}=2.36, \mathrm{~g}_{2}=2.18$ and $\mathrm{g}_{3}=1.92$. In contrast, the spectra of $\left[\mathrm{Fe}^{\mathrm{III}}(\mathrm{CN})_{5}(\mathrm{bzoxs})\right]^{2-}$ and of $\left[\mathrm{Fe}^{\mathrm{III}}(\mathrm{CN})_{5} \text { (shpyNO) }\right]^{2-}$ are typically axial with identical $\mathrm{g}_{/ /}=1.96$ and $\mathrm{g}_{\perp}=2.20$ values (Figure 3). These results strengthen our previous conclusion of bzoxs being

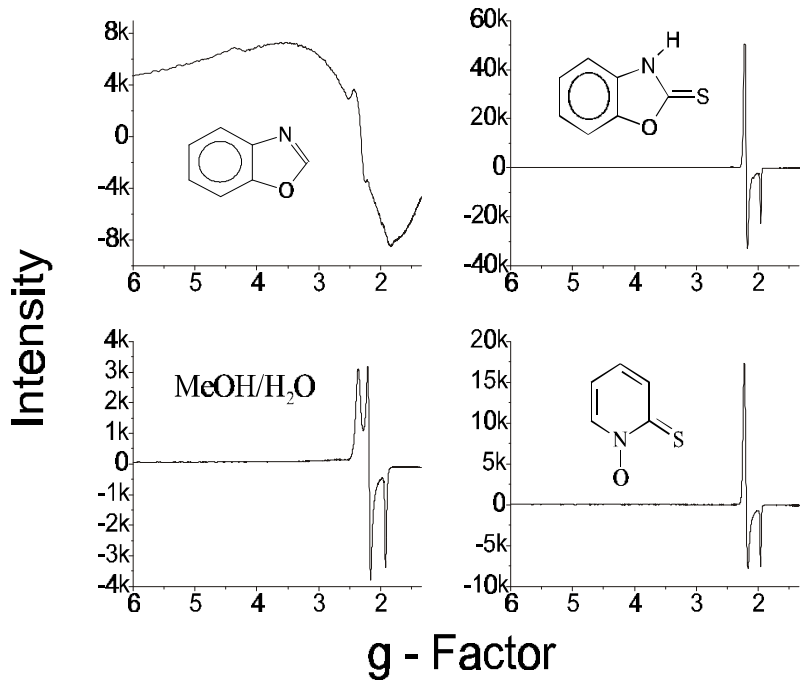

Figure 3. Epr spectra of pentacyanoferrate(III) complexes at $77 \mathrm{~K}$. coordinated to iron(III) through the sulfur atom, as suggested by the UV-Vis data.

\section{Conclusions}

Although the theoretical calculations for bzoxs have indicated some nucleophilic character for the nitrogen atom, the steric relief provided by the sulfur coordination probably provides the driving force responsible for the thermodynamic stability of both the $\mathrm{Fe}^{\mathrm{II}}$ and $\mathrm{Fe}^{\mathrm{III}}$ pentacyanoferrate-bzox complexes. Moreover, spectroscopic, electrochemical as well as thermodynamic and kinetic $^{9}$ data altogether have given strong support for preferential sulfur coordination.

The following spectrochemical order was obtained: benzoxazole > 2-mercaptopyridine $\mathrm{N}$-oxide > dimethylsulfide $>$ dithioxamide $>$ thioacetamide $>$ thiourea $>2$-mercaptobenzoxazole, consistent with the presence of the thioamide group in bzoxs and also showing that it provides a weak ligand field.

\section{Acknowledgements}

This work was supported by Brazilian PRONEX Program (Contract Number 41.96.0884.00), whose help we gratefully acknowledge. We thank Prof. Henrique Eisi Toma (Institute of Chemistry - USP, Brasil) and Prof. Carlos J. da Cunha (DQ-UFPR, Brasil) for the valuable suggestions. J.E.B and D.J.E thank the Biotechnology and Biological Sciences Research Council, UK for funding. J.B.L thanks UFPR and Brazilian Research Council (CAPES) for a research fellowship.

\section{References}

1. Baraldo, L. M.; Forlano, P. F.; Parise, A. R.; Slep, L. D.; Olabe, J. A.; Coord. Chem. Rev. 2001, 219-221, 881; Sieklucka, B.; Proc. React. Kinet. Mec. 1999, 24, 165; Burguess, J. In Mechanisms of Inorganic and Organometallic Reaction; Twigg, M.V., ed., Plenum: New York, 1994, p. 155.

2. Toma, H. E.; Batista, A. A.; Gray, H. B.; J. Am. Chem. Soc. 1982, 104, 7509 .

3. Toma, H. E.; Giesbrecht, E.; Espinoza Rojas, R. L.; Can. J. Chem. 1983, 61, 2520; Toma, H. E.; Martins, J. M.; J. Chem. Soc., Dalton Trans. 1978, 1610; Toma, H. E.; Takayasu, M.; An. Acad. Bras. Cienc. 1989, 61, 131;

4. Toma, H. E.; Batista, A. A.; J. Inorg. Biochem. 1984, 20, 53.

5. Yan, C. W.; Lin, H. C.; Cao, C. N.; Electrochimica Acta 2000 , 45, 2815; Preti, C.; Tosi, G.; J. Inorg. Nucl. Chem. 1976, 38 , 1125; Khanova, L. A.; Merenkova, M. V.; Efremov, B. N.; Tarashevich, M. R.; Russian J. Electrochem. 1993, 89, 952. 
6. Szachowski, K.; Oszajca, J.; Stochel, G.; Stasicka, Z.; J. Chem. Soc., Dalton Trans. 1999, 2353.

7. Preti, C.; Tosi, G.; Can. J. Chem. 1976, 54, 85; Preti, C.; Tosi, G.; J. Coord. Chem. 1978, 8, 15; Preti, C.; Tosi, G.; Spectrochim. Acta 1979, 35A, 577; Vicente, J.; Chicote, M. T.; Herrero, P. G.; Jones, P. G.; J. Chem. Soc., Dalton Trans. 1994, 3183; Vicente, J.; Chicote, M. T.; Rubio, D.; Chem. Ber. 1996, 129, 327; Bandbury, F. A.; Davidson, M. G.; Rai They, P. R.; Stalke, D.; Snaith, R. J.; J. Chem. Soc., Dalton Trans. 1995, 3139; Preti, C.; Tosi, G.; Can. J. Chem. 1977, 55, 1409.

8. Balestero, R. S.; Forkey, D. M.; Russel, J. G.; Magnetic Reson. Chem. 1986, 24, 651

9. Luiz, J. B.; Leigh; G. J.; Nunes, F. S.; Polyhedron 2002, 21 , 2137.

10. Maciejowska, I.; Stasicka, Z.; Stochel, G.; van Eldik, R.; J. Chem. Soc., Dalton Trans. 1999, 3643; Stochel, G.; van Eldik, R.; Inorg. Chim. Acta 1991, 190, 55; Alshehri, S.; Burguess, J.; van Eldik, R.; Hubbard, C. D.; Inorg. Chim. Acta 1995, 240, 305; Lin, C. L.; Hung, K.; Yeh, A.; Inorg. Chem. 1999, 38, 411; Chen, C. N.; Wu, M. C.; Yeh, A.; Tsai, T. Y. R.; Inorg. Chim. Acta 1998, 267, 81; Toma, H. E.; Chavez-Gil, T. E.; Spectroscopy Letters 1999, 32, 963; Norris, P. R.; Harper, P. L. S.; Pratt, J. M.; J. Chem. Soc., Dalton. Trans. 1997, 2505;
Almaraz, A. E.; Gentil, L. A.; Baraldo, L. M.; Olabe, J. A.; Inorg. Chem. 1996, 35, 7718.

11. Brauer, G.; Handbook of Preparative Inorganic Chemistry, Academic Press: New York, $2^{\text {nd }}$ ed., 1965, vol. 2, p. 1511.

12. Gale, R.; McCaffery, A. J.; J. Chem. Soc., Dalton Trans. 1973, 1344.

13. Toma, H. E.; Takasugi, M. S.; Polyhedron 1982, 1, 429.

14. Toma, H. E.; Nunes, F. S.; Anais do VI Simpósio Brasileiro de Eletroquímica e Eletroanalítica, Ribeirão Preto-SP, 1988.

15. Baran, Y.; Ülgen, A.; Intern. J. Chem. Kinet. 1998, 30, 415.

16. Batista, A. A.; PhD Thesis, Universidade de São Paulo, Brazil, 1982.

17. Manoharan, P. T.; Gray, H. B.; J. Am. Chem. Soc. 1965, 87, 3340.

18. Gray, H. B.; Ballhausen, C. J.; J. Chem. Phys. 1962, 36, 1151.

19. Toma, H. E.; Giesbrecht, E.; Malin, J. M.; Fluck, E.; Inorg. Chim. Acta 1975, 14, 11.

20. Toma, H. E.; Martins, J. M.; Giesbrecht, E.; Inorg. Chem. 1973, 12, 2084.

21. Borges, S. S. S.; Coelho, A. L.; Moreira, I. S.; Araújo, M. A. B.; Polyhedron 1994, 13, 1015.

Received: November 11, 2002 Published on the web: September 24, 2003 